\title{
Pariwisata Wakatobi dalam Perspektif Produksi Ruang
}

\author{
Muhammad Al Dilwan ${ }^{1}$, I Komang Astina ${ }^{1}$, Syamsul Bachri ${ }^{1}$ \\ ${ }^{1}$ Pendidikan Geografi-Universitas Negeri Malang
}

\section{INFO ARTIKEL}

\section{Riwayat Artikel:}

Diterima: 13-05-2019

Disetujui: 14-11-2019

\section{Kata kunci: \\ wakatobi tourism, space production; pariwisata wakatobi; produksi ruang}

Alamat Korespondensi:
Muhammad Al Dilwan
Pendidikan Geografi
Universitas Negeri Malang
Jalan Semarang 5 Malang
E-mail: dilwanmuhammad@ gmail.com

\section{ABSTRAK}

Abstract: Tourism is the primary sector of Wakatobi. This research aims to reveal the process of spatial formation of Wakatobi tourism space. The study was designed to use a qualitative method with a case study approach. The results of the research show that Wakatobi tourism space production process started the involvement of the public and the private sector in tourism management, the spatial policy of the determination of Wakatobi as a tourism area, and people that perceived their territory as a tourism space.

Abstrak: Pariwisata adalah sektor utama Wakatobi. Penelitian ini bertujuan untuk mengungkapkan proses spasial terbentuknya ruang pariwisata Wakatobi. Penelitian dirancang menggunakan metode kualitatif dengan pendekatan studi kasus. Hasil penelitian menunjukkan proses produksi ruang pariwisata Wakatobi dimulai dari keterlibatan masyarakat dan swasta dalam pengelolaan pariwisata, kebijakan spasial penetapan Wakatobi sebagai kawasan pariwisata dan pemikiran masyarakat yang memersepsikan wilayahnya sebagai ruang pariwisata.

Wakatobi adalah kawasan pariwisata dan kawasan taman nasional. Wakatobi terletak di kawasan segi tiga terumbu karang dunia dengan tingkat keragaman hayati kelautan yang tinggi (Purbani et al., 2014). Wilayah laut Wakatobi memiliki 750 spesies karang dan 942 spesies ikan (Pet-Soede \& Erdmann, 2003). Keanekaragaman hayati kelautan adalah dasar pembentukan Wakatobi menjadi kawasan pariwisata dan kawasan taman nasional. Keberadaan beragam jenis biota laut merupakan daya tarik masuknya beragam kepentingan untuk memanfaatkan nilai ekonomi ruang laut Wakatobi. Pemerintah, swasta dan masyarakat adalah aktor utama yang berupaya memanfaatkan potensi ekonomi ruang laut tersebut. Kawasan taman nasional Wakatobi ditunjuk pada 1996. Pembentukan taman nasional adalah upaya negara mengklaim kepemilikan kawasan (state properti right) secara top-down (Kosmaryandi et al., 2012). Pengelolaan kawasan taman nasional menggunakan sistem zonasi. Wilayah Wakatobi dipilah menjadi zona konservasi dan zona budidaya (Taman Nasional Wakatobi, 2007). Zona konservasi adalah zona larang tangkap. Zona konservasi, meliputi zona inti, zona pemanfaatan bahari, dan zona pariwisata. Zona budidaya adalah zona bebas tangkap. Zona budidaya, meliputi zona pemanfaatan umum, zona pemanfaatan lokal, dan zona khusus darat.

Masyarakat adat Wakatobi (sara kadie) adalah pengelola kawasan sebelum masuknya taman nasional. Teritorial pengontrolan adat meliputi daratan dan lautan. Adat mengelola kawasan berdasarkan prinsip keseimbangan alam dan prinsip keadilan (Hanan, 2010). Sistem pengelolaan adat tergambar melalui penerapan zonasi lokal. Masyarakat adat membagi ruang laut menjadi ruang pemanfaatan dan ruang perlindungan. Ruang pemanfaatan adalah tempat nelayan melakukan aktivitas kenelayanannya. Penggunaan teknologi merupakan salah satu perhatian adat. Perhatian terhadap teknologi dilakukan agar nelayan lokal yang memiliki teknologi terbatas tidak terjebak persaingan dan konflik ruang. Keberadaan zonasi taman nasional menyebabkan teritorial kekuasaan adat terdegradasi.

Swasta merupakan salah satu aktor penting dalam pemanfaatan nilai ekonomi ruang laut Wakatobi. Keterlibatan pihak swasta bersamaan dengan penetapan Wakatobi sebagai kawasan wisata alam pada 1995. Informan Agam menuturkan bahwa Operation Wallacea adalah pengelola pariwisata yang beroperasi sejak 1994 (Wawancara, 21 Mei 2018). Wakatobi Dive Resort adalah perusahaan pariwisata yang mulai beroperasi pada 1995 (Fachry et al., 2010). Pemekaran Wakatobi menjadi kabupaten otonom pada 2003 merupakan kesempatan penting wilayah untuk berkembang lebih pesat. Pariwisata dan perikanan merupakan dua sektor pilihan pengembangan wilayah. Masyarakat mulai berorganisasi dan diorganisir untuk memaksimalkan pemanfaatan potensi nilai ekonomi ruang laut Wakatobi (RPPW, 2013).

Keanekaragaman hayati laut Wakatobi merupakan nilai tawar utama pariwisata daerah. Keindahan bawah laut juga menjadi dasar pemerintah merumuskan visi pembangunan kepariwisataan Terwujudnya Wakatobi sebagai Destinasi Ekowisata Berkelas Dunia dan Berbasis Masyarakat 2016-2025 (Perda Wakatobi No. 4 Tahun 2017). Visi ini adalah kelanjutan dari visi pemerintah periode 2006-2016 yaitu Terwujudnya Surga Nyata Bawah Laut di Pusat Segi Tiga Karang Dunia (Pemkab Wakatobi, 2012). 
Keadaan pariwisata Wakatobi mengalami perkembangan. Pemerintah mencanangkan program 10 Destinasi Unggulan Pariwisata Indonesia 2015-2019. Sepeluh destinasi yang terpilih adalah Danau Toba, Tanjung Kelayang, Tanjung Lesung, Kepulauan Seribu, Borobudur, Bromo-Tengger-Semeru, Mandalika, Labuan Bajo, Wakatobi dan Morotai (Peraturan Menteri Pariwisata No. 29 Tahun 2015). Program ini bertujuan untuk memercepat pembangunan pariwisata. Target pemerintah adalah kunjungan 20 juta wisatawan mancanegara pada tahun 2019 dapat tercapai.

Badan Otorita Pariwisata (BOP) adalah organisasi yang dibentuk di setiap 10 destinasi terpilih untuk mengelola pengembangan pariwisata. Penetapan BOP Wakatobi ditentang masyarakat dengan melakukan unjuk rasa pada 25 Mei 2016 (Tempo.co, 2016). BOP adalah lembaga pengelola pariwisata yang dianggap akan memberikan dominasi maksimal kepada pemerintah dan swasta sementara peran masyarakat diminimalkan (Hajratul et al., 2018).

Pariwisata Wakatobi adalah ruang sosial yang dikonstruksi secara sosial. Menurut Lefebvre (1991) "ruang adalah produk sosial". Ruang merupakan produk yang berasal dari aktivitas individual dan kolektif manusia. Ruang yang diproduksi bersifat dinamis, berubah ketika manusia berubah. Manusia dapat memengaruhi ruang (Ramantika et al., 2015) dan ruang dapat memengaruhi manusia (Anggraeni \& Sunaryo, 2015). Ruang pariwisata Wakatobi terus mengalami perubahan. Perubahan spasial menginterpretasikan perubahan sosial.

Ruang sosial adalah konsep ruang yang berasal dari perspektif kualitatif. Ruang sosial adalah tempat terjadinya relasi dan interaksi antar individu (Prasetyo, 2013). Munculnya beragam pola penggunaan ruang ditentukan oleh cara ruang dirasakan dan diyakini. Fokus dari ruang sosial adalah realitas yang dirasakan bukan yang diukur (Hall dalam Setiadi, 2007).

Manusia adalah produsen ruang sosial. Proses pembentukan ruang dijelaskan melalui konsep triadik produksi ruang, yaitu praktik spasial, representasi ruang dan ruang representasi (Lefebvre, 1991). Triadik produksi ruang adalah tiga konsep pembentuk ruang yang saling berkaitan. Konsep triadik produksi ruang ini digunakan untuk mengungkapkan proses spasial terbentuknya ruang pariwisata Wakatobi.

\section{METODE}

Penelitian dilaksanakan di kabupaten Wakatobi pada Mei 2018. Metode analisis yang digunakan adalah kualitatif. Metode kualitatif merupakan proses inkuiri, mengeksplorasi masalah sosial (Creswell, 2015; Moleong, 2017). Penelitian ini menggunakan data primer dan sekunder. Data primer berasal diperoleh secara langsung melalui wawancara dan observasi. Data sekunder penelitian dihimpun dari kajian kepustakaan yang berasal dari jurnal ilmiah, buku, maupun dari data yang bersumber dari instansi terkait. Data penelitian dianalisis menggunakan metode Miles dan Huberman (1994), yaitu reduksi data, penyajian data, dan verifikasi data. Hasil penelitian dikombinasikan konsep triadik produksi ruang Lefebvre untuk menganalisis proses spasial terbentuknya ruang pariwisata Wakatobi.

\section{HASIL DAN PEMBAHASAN Proses Pembentukan Ruang Pariwisata Wakatobi Interaksi Manusia dan Ruang}

Ruang laut Wakatobi pada awalnya merupakan sumber penghidupan masyarakat melalui aktivitas kenelayanan. Masyarakat tidak mengenal pariwisata dalam arti industri. Aktivitas pariwisata dimulai ketika Wakatobi Dive Resort (WDR) dan Operation Wallacea (Opwall) mendirikan perusahaan di Wakatobi pada tahun 1995-an.

Lorenz mendirikan Wakatobi Dive Resort (WDR) di Pulau Tolandono, Desa Lamanggau, Kecamatan Tomia. Aktivitas pariwisata perusahaan berawal dari pelibatan masyarakat dalam bisnis konservasi. Area-area aktivitas kenelayanan yang dinalisis merupakan tempat penting keberlangsungan ekosistem laut diproteksi dan menjadi konsensus bisnis. Masyarakat melindungi area konservasi. Timbal-baliknya adalah masyarakat memeroleh keuntungan dari anggaran tiap bulan yang diberikan perusahaan kepada 17 desa mitra program. Kontribusi WDR berupa uang dengan nominal bervariasi, disesuaikan dengan tingkat kontribusi desa. Keuntungan lain yang diperoleh masyarakat adalah kesempatan menjadi karyawan perusahaan, mendapatkan pasokan listrik dan suplai air tawar kepada beberapa desa mitra resort berpenduduk sekitar 500 jiwa.

Operation Wallacea (Opwall) adalah perusahaan yang beroperasi di Pulau Hoga. Opwall membangun relasi bisnis dengan masyarakat. Lahan-lahan yang semula ditumbuhi rerumputan dan pepohonan diubah menjadi perumahan. Warga mendirikan rumah untuk disewakan kepada wisatawan melalui perantara manajemen Opwall. Masyarakat menyediakan sekitar 200 home stay di Pulau Hoga.

Aktivitas kepariwisataan yang terjadi di Wakatobi antara WDR, Opwall dan masyarakat adalah bentuk praktik spasial. Praktik spasial adalah praktik sosial (Lefebvre, 1991). Ruang yang dihasilkan adalah ruang hidup (lived space), ruang yang dikonstruksi melalui interaksi antar manusia dan lingkungan. Penghuni ruang bersentuhan secara langsung dengan simbolsimbol ruang yang berbentuk fisik. Keanekaragaman hayati laut Wakatobi adalah simbol fisik yang dimanfaatkan sebagai objek wisata alam laut. Praktik spasial pariwisata mengalami perkembangan saat status administratif Wakatobi berubah menjadi kabupaten pada 2003. Pariwisata adalah sektor unggulan ekonomi daerah. Masyarakat sacara langsung dan tidak langung berorganisasi dan diorganisasi menjadi pelaku usaha pariwisata baik sebagai karyawan maupun pemilik usaha. Praktik spasial pariwisata tergambar melalui penyediaan jasa pariwisata. Tempat usaha pariwisata di Wakatobi berjumlah 180 buah yang terdiri dari usaha akomodasi, tempat makan, hiburan, perawatan diri, dan tempat usaha oleh-oleh (Dispar, 2017). 
Praktik spasial pariwisata bukan saja terjadi secara lokal di Wakatobi, tetapi merupakan fenomena nasional dan global. Praktik yang muncul merupakan imbas dari meningkatnya volume wisatawan dalam negeri dan mancanegara yang dimanfaatkan pemerintah dan swasta untuk meningkatkan perekonomian. Jumlah wisatawan dunia adalah 25 juta orang pada 1950. Jumlah wisatawan meningkat menjadi 278 juta orang pada tahun 1980, 528 juta orang pada tahun 1995 dan pada tahun 2014 berjumlah 1,1 miliar orang. Jumlah wisatawan dunia diproyeksikan mencapai 1,602 miliar orang pada tahun 2020 (World Tourism Organitation, 2019). Ruang pariwisata diproduksi untuk memanfaatkan potensi ekonomi dari penngkatan jumlah wisatawan.

Wisatawan adalah sumber peningkatan ekonomi daerah tujuan wisata. Aktivitas penyedia jasa pariwisata, kedatangan wisatawan, program pemberdayaan pemerintah dan interaksi antara semua aktor merupakan komponen praktik spasial yang terus berlangsung. Aktivitas pariwisata adalah praktik spasial pembentuk ruang pariwisata Wakatobi. Ruang pariwisata Wakatobi terus diproduksi melalui praktik spasial untuk memanfaatkan nilai ekonomi dari aktivitas pariwisata. Memberikan pelayanan untuk keperluan wisatawan dan melestarikan lingkungan adalah praktik spasial pariwisata yang dapat meningkatkan perekonomian.

\section{Ruang Imajiner Pariwisata}

Ruang pariwisata Wakatobi tidak hanya diproduksi melalui praktik spasial, tetapi juga diproduksi dalam bentuk ruang imajiner. Ruang imajiner tergambar dalam peta kawasan strategis pariwisata nasional yang tertera pada Rencana Induk Pembangunan Kepariwisataan Nasional (Ripparnas) 2010-2025 (PP No. 50 Tahun 2011). Dalam Ripparnas diimajinasikan bahwa di Indonesia terdapat 222 kawasan pengembangan pariwisata nasional (KPPN), 50 destinasi pariwisata nasional (DPN) dan 88 kawasan strategis pariwisata nasional (KSPN). Ruang pariwisata Wakatobi tergambar dalam KSPN dan pada 2016 terpilih menjadi bagian dari 10 daerah prioritas pembangunan pariwisata nasional (Peraturan Menteri Pariwisata No. 29 Tahun 2015). Dalam konsep Lefebvre (1991) ruang imajinar pariwisata merupakan bentuk dari konsep representasi ruang.

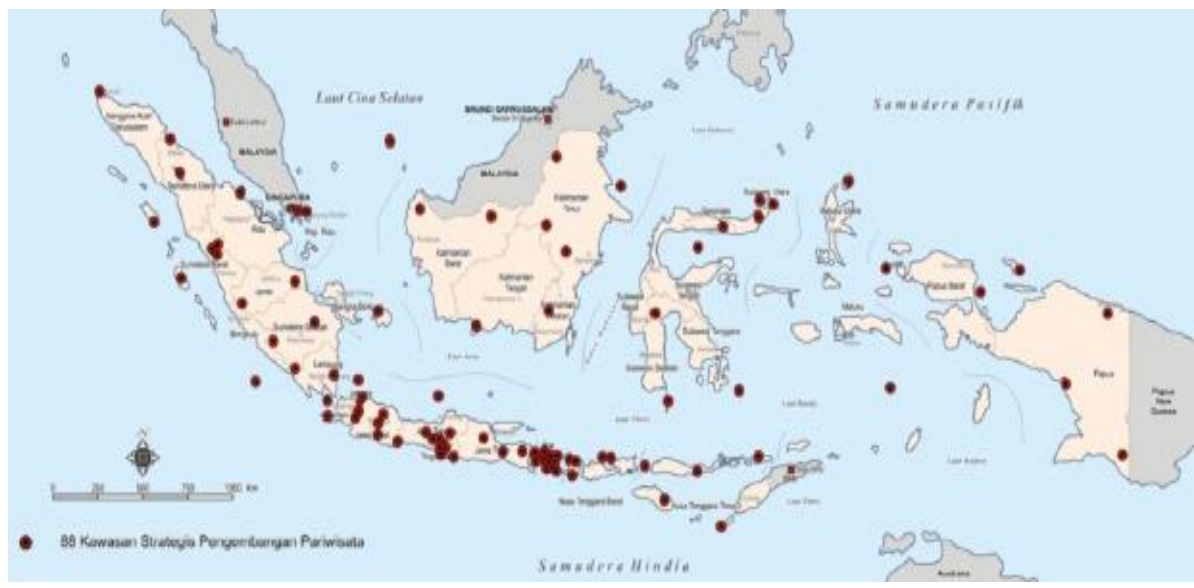

Gambar 1. Peta Kawasan Strategis Pengembangan Pariwisata Nasional

Ruang pariwisata di produksi secara imajiner dengan tujuan memetakan wilayah berpotensi ekonomi. Sepuluh daerah prioritas pembangunan pariwisata nasional memiliki potensi pariwisata yang tinggi, tetapi investasi dan infrastruktur dasar masih terbatas. Kesepuluh destinasi tersebut adalah Danau Toba, Tanjung Kelayang, Tanjung Lesung, Kepulauan Seribu, Borobudur, Bromo-Tengger-Semeru, Mandalika, Labuan Bajo, Wakatobi, dan Morotai. Keindahan alam dan kemegahan warisan budaya yang berada di 10 destinasi terpilih akan mudah terakses bila kebutuhan wisatawan terpenuhi. Pembentukan ruang imajiner 10 destinasi unggulan dimaksudkan untuk mengatasi persoalan pariwisata yang pengelolaannya diserahkan kepada BOP (Badan Otorita Pariwisata). BOP adalah lembaga integral antar kementerian, antara pemerintah daerah dan pusat, yang bertujuan mempercepat pengembangan amenitas, aksesibilitas, dan atraksi di daerah tujuan wisata. 


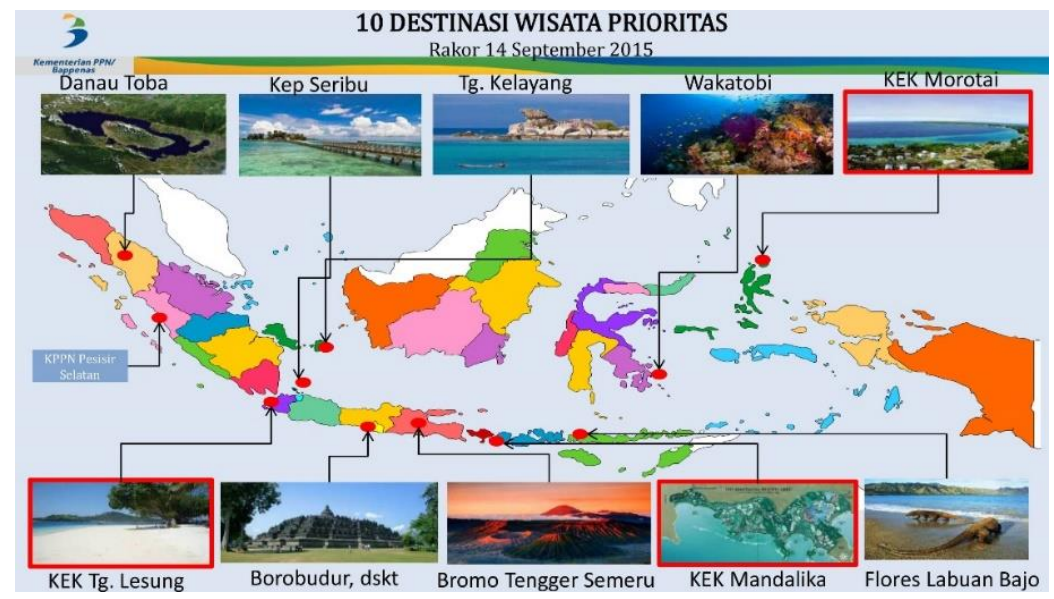

Gambar 2. Peta 10 Destinasi Prioritas

Ruang pariwisata yang dirumuskan dalam program 10 destinasi unggulan adalah ruang imajiner. Dalam ruang yang direncanakan juga tergambar wilayah kerja BOP yang berfungi sebagai ruang koordinatif dan ruang pengembangan industri pariwista. Ruang kerja BOP di Wakatobi diimajinasikan seluas lima ribu hektar area yang terdistribusi di Wangi-wangi, Kaledupa, Tomia, dan Binongko. Semua ruang ini direncanakan mampu menampung 500 ribu wisatawan. Lima ribu hektar yang disediakan adalah bentuk keseriusan pemerintah daerah dan bentuk sinergitas antara pemda dam pemerintah pusat. Pada ruang imajiner pengembangan industri, pengelolaanya akan diserahkan kepada pihak swasta. Dalam perspektif nilai ekonomi yang menempatkan swasta sebagai aktor penggerak, ruang yang disediakan adalah moda produksi keuangan.

Ruang imajiner pariwisata adalah konsep kedua produksi ruang. Ruang yang diproduksi adalah ruang abstrak. Para perancang membentuk ruang abstrak melalui imajinasi dan pengetahuan matematis. Ruang yang dihasilkan tervisualisasi dalam bentuk peta kawasan pariwisata. Ruang abstrak dianggap sebagai ruang ideal oleh para perancangnya. Ruang imajiner bersifat determinan mampu mengintervensi dan memodifikasi struktur dan pola keruangan. Pada akhrinya ruang abstrak yang dihasilkan menjadi the locus of a theoretical practice, referensi tindakan (Lefebvre, 1991).

Ruang pariwisata Wakatobi adalah ruang imajinatif yang dikonstruksi menggunakan perspektif kuantitatif. Perspektif ini memudahkan perancang mengonstruksi ruang pariwisata. Dalam perspektif kuantitatif, Wakatobi adalah ruang fisik yang memiliki bentuk dan ukuran serta bersifat objektif dan stabil. Masyarakat dianggap kumpulan objek yang menjadi basis pengukuran dan penghitungan. Perspektif kuantitatif merupakan instrumen penting dalam perencanaan ruang yang disebut sebagai sistem perencanaan rasional (Saraswati, 2006). Sesuai dengan basis kuantitatifnya, model perencanaan rasional bergantung kepada ketersediaan data akurat berupa angka-angka.

Perpektif kuantitatif mendomiasi perencanaan ruang pariwisata Wakatobi. Pengembangan wilayah pariwisata yang mengutamakan aspek fisik menyebabkan aspek sosial terabaikan. Konsepsi masyarakat dan hubungan antar manusia dalam ruang adalah salah satu aspek sosial yang dialpakan. Aspek budaya dan sosial yang dimiliki masyarakat Wakatobi adalah modal penting pembangunan pariwisata (Udu, 2017). Akan tetapi, aspek budaya dan sosial belum mendapatkan posisi penting dalam representasi ruang.

Ciri sederhana yang dapat dtunjukkan dari analisis ruang secara kuantitatif adalah penggunaan pengambaran ruang dua dimensi dan tiga dimensi dalam bidang pemetaan. Basis data pemetaan adalah eksplorasi ruang yang diperoleh melalui studi ilmiah untuk mengetahui keberadaan potensi wilayah dan persebarannya. Ruang pariwisata Wakatobi yang tervisualisasi dalam bentuk peta merupakan hasil dari eksplorasi sumber daya ruang. Studi ilmiah dilakukan sejak 1980-an oleh beragam organisasi. Eksplorasi pertama adalah Ekspedisi Snellius II pada 1984-1985 (Nontji, 2017). Ekspedisi juga dilakukan pada September 1986 oleh Tim Ditjen PHPA bekerjasama dengan WWF (Rudianto \& Santoso, 2008). Pada 1995 studi potensi bahari kembali dilakukan. Pelaksananya adalah Tim Operation Wallacea yang disponsori Lembaga Ilmu Pengetahuan Indonesia (LIPI), Institut Pengembangan Wallacea (WDI) dan Direktorat Jenderal Kehutanan dan Konservasi (PHPA) dengan dukungan dana dari Hong Kong Bank Care-for-Nature Programme (Erdmann, 2007). Hasil eksplorasi ruang menunjukkan bahwa kawasan laut Wakatobi memiliki kekayaan sumber daya alam. Hasil ekspedisi menjadi rujukan pembentukan kawasan taman nasional pada 1996. Pembentukan taman nasional bertujuan untuk melestarikan ekosistem kelautan yang selanjutnya dapat dimanfaatkan untuk kepentingan masyarakat.

Wilayah Wakatobi memenuhi persyaratan pembentukan ruang pariwisata. Wilayah laut Wakatobi memiliki 750 spesies karang dan 942 spesies ikan (Pet-Soede \& Erdmann, 2003). Keanekaragaman hayati Wakatobi merupakan aspek fisik daya tarik wisata alam laut (Saputro, 2013; Purwanto et al., 2015; Muis et al., 2016). Sumber daya laut Wakatobi dianggap dapat meningkatkan perekonomian masyarakat lokal secara khusus dan masyarakat Indonesia pada umumnya melalui praktik spasial pariwisata. 
Studi ilmiah kelautan adalah implikasi dari kebijakan nasional yang mencanangkan pariwisata sebagai sektor ekonomi unggulan pada dekade 1980-an. Pemerintah menganggap pariwisata adalah sektor ekonomi yang cenderung stabil ditengah dinamika ekonomi global. Jumlah wisatawan dunia terus meningkat dan kondisi ekonomi dunia yang labil tidak terlalu memengaruhinya. Stabilitas sektor pariwisata memotivasi dilakukannya ekspedisi dalam rangka memetakan potensi bahari sebagai bagian dari eksplorasi potensi pariwisata nasional. Beragam jenis biota laut yang ditemukan bukan saja menjadi dasar pembentukan kawasan taman nasional, tetapi juga merupakan dasar produksi ruang pariwisata. Menjadikan Wakatobi sebagai kawasan konservasi adalah strategi untuk menjamim kelangsungan daya tarik wisata alam laut. Produksi ruang taman nasional dan pariwisata Wakatobi motifnya adalah konservasi dan ekonomi. Instrumen politik dalam bentuk kebijakan spasial digunakan untuk mengefisiensikan nilai konservasi dan nilai ekonomi.

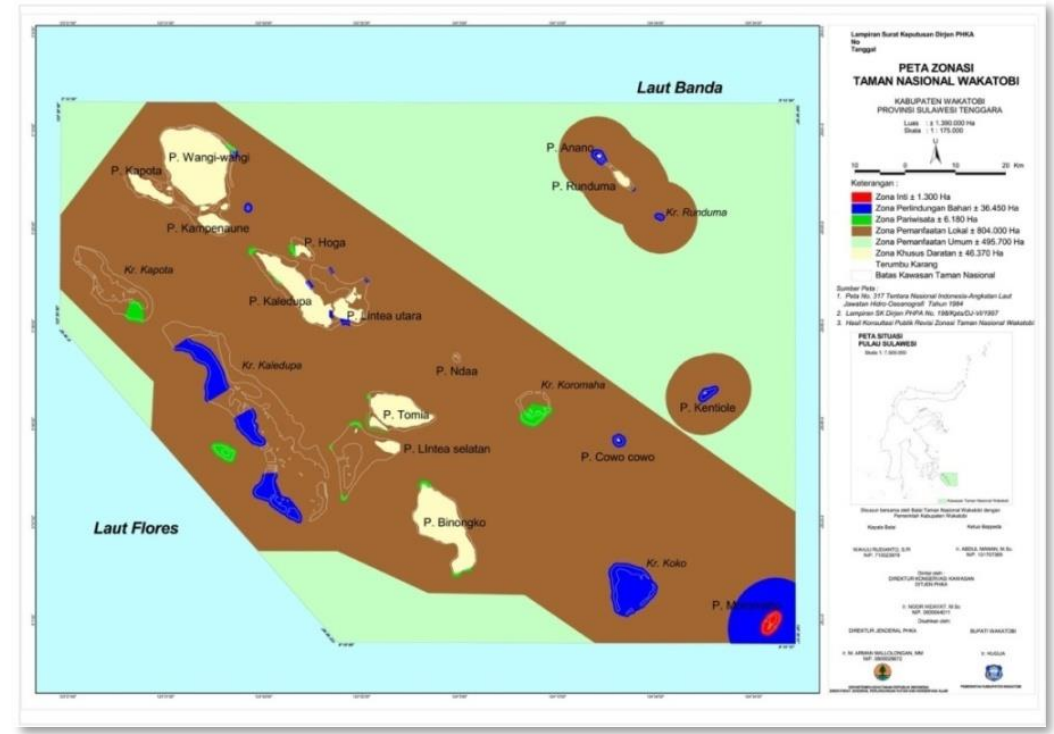

Gambar 3. Peta Zonasi Taman Nasional Wakatobi

Nilai ekomoni yang berada dibalik kebijakan spasial merupakan strategi yang berasal dari konsep kapitalisme. Kapitalisme bekerja melalui kecakapan spasial, teknik tata ruang (Rachman, 2018). Kecakapan spasial adalah modal utama melakukan ekspansi ekonomi yang berjalan pada semua sektor pembangunan mulai dari proyek pertambangan, kehutanan, perkebunan, infrastruktur hingga ke pariwisata. Kecakapan spasial dimanfaatkan untuk meningkatkan kapital. Akumulasi kapital tidak akan terjadi tanpa adanya ruang. Oleh karena itu, hal mendasar yang perlu dilakukan adalah merancang dan menetapkan kebijakan spasial.

Wakatobi menyandang dua status ruang, yaitu ruang konservasi dan pariwisata. Representasi kedua ruang tampak melalui peta zonasi taman nasional dan peta kawasan strategis pariwisata nasional. Konservasi dan pariwisata adalah dua komponen ruang yang saling bertautan di Wakatobi. Konservasi adalah strategi pelestarian lingkungan. Pariwisata adalah strategi memanfaatkan nilai ekonomi dari pelestarian sumber daya laut Wakatobi.

Kawasan taman nasional dan kawasan strategis pariwisata merupakan ruang abstrak yang memiliki kekuatan memodifikasi dan mengubah praktik spasial. Masyarakat adat adalah pengelola kawasan sebelum Wakatobi dirancang menjadi kawasan taman nasional. Pembentukan taman nasional pada 1996 adalah kebijakan spasial yang mengubah praktik spasial masyarakat. Teritorial kekuasaan adat menghilang dan pola pemanfaatan ruang laut harus disesuaikan dengan sistem zonasi taman nasional (Hanan, 2010). Praktik spasial masyarakat berubah mengikuti zonasi formal pemerintah. Hal ini dapat terjadi karena representasi ruang taman nasional memiliki daya untuk memengaruhi praktik spasial. Ruang imajiner bersifat determinan, mampu mengubah dan mengatur perilaku masyarakat sesuai yang dikehendaki perancang ruang (Lefebvre, 1991). Pemberian sangsi kepada tindakan masyarakat yang tidak sesuai dengan sistem zonasi adalah strategi agar praktik spasial sesuai dengan ruang imajiner.

Pembentukan ruang pariwisata Wakatobi dianggap kebijakan spasial yang tepat. Hal ini terjadi karena representasi ruang merupakan ruang ideal bagi para perancangnya. Idealitas ruang berasal dari konstruksi ruang yang menggunakan perspektif kuantitatif. Ruang Wakatobi dipersepsikan sebagai realitas fisik yang dapat diobjektifikasi. Objektifikasi menandakan bahwa ruang adalah realitas terukur. Pada titik ini, ruang adalah objek yang pasif serta dapat ditata oleh para perancang. Tata ruang tervisualisasi menjadi peta kawasan taman nasional dan kawasan strategis pariwisata nasional. Praktik spasial masyarakat dituntut sesuai visualisasi tersebut. Penyesuaian tindak perlu dilakukan karena ruang abstrak yang dihasilkan merupakan the locus of a theoretical practice dan alat kekuasaan yang digunakan untuk mengatur cara masyarakat bertindak dan berpikir (Lefebvre, 1991). 


\section{Persepsi Ruang Masyarakat}

Ruang representasional adalah pembentuk ruang pariwisata Wakatobi. Ruang representasional adalah lived experience, ruang berlangsungnya kehidupan (Lefebvre, 1991). Ruang representasional adalah ruang nyata, tempat terjadinya interaksi antar masyarakat dan objek dalam ruang. Interaksi tersebut membentuk pengalaman. Pengalaman adalah basis pengetahuan pembentuk persepsi, penilaian terhadap ruang yang ditempati. Persepi masyarakat adalah pembentuk ruang pariwisata Wakatobi.

Ruang memiliki arti fisik, mental dan sosial. Dalam arti fisik, ruang memiliki ukuran dan objek-objek dalam ruang berhubungan secara pasif. Ruang dalam arti mental adalah ruang imajinatif yang dapat terlihat dalam bentuk peta. Dalam arti sosial, ruang merupakan tempat berlangsungnya aktivitas kehidupan masyarakat yang ditandai dengan tindakan dan persepsi. Aktivitas sosial terjadi karena adanya persepsi. Persepsi masyarakat ini bersifat dinamis, dapat mengalami perubahan. Cara ruang digunakan sehingga membentuk pola penggunaan ruang bergantung kepada persepsi masyarakat tentang ruang yang ditempatinya. Konsepsi masyarakat tentang pariwisata adalah pembentuk ruang pariwisata Wakatobi.

Sebelum Wakatobi Dive Resort dan Operation Wallacea beroperasi di Wakatobi aktivitas masyarakat dominan berada pada sektor pertanian, kelautan, dan berladang. Ketika perusahaan pariwisata masuk pada tahun 1995-an dan bekerjasama dengan masyarakat konsepsi masyarakat atas ruang yang dihuni mulai berubah. Ruang yang selama ini termanfaatkan untuk kegiatan pertanian dapat juga digunakan untuk kegiatan industri pariwisata. Beragam jenis terumbu karang dan ikan tidak hanya berfungsi untuk memenuhi kebutuhan pangan, tetapi merupakan atraksi pariwisata. Kesadaran pariwisata masyarakat mulai tumbuh meskipun belum secara menyeluruh.

Perubahan status Wakatobi menjadi wilayah administrasi kabupaten merupakan momentum perkembangan konsepsi masyarakat tentang ruang pariwisata. Pemerintah menempatkan pariwisata sebagai sektor unggulan daerah. Kebijakan ini dadasarkan pada potensi bahari Wakatobi yang memiliki ratusan spesies ikan dan terumbu karang. Ruang pariwisata kemudian dirumuskan dan dituangkan dalam rencana strategis pengembangan pariwisata. Hal ini tertera dalam perencanaan ruang daerah dan nasional. Beberapa wilayah zonasi menjadi kawasan pengembangan. Infrastruktur yang didirikan antara lain adalah jaringan transportasi darat, laut, dan udara yang diarahkan untuk mewujudkan visi pembangunan daerah yang fokus terhadap pariwisata.

Ruang yang direncanakan pemerintah menjadi bagian pemantik perubahan konsepsi masyarakat terhadap ruang yang dihuni. Sumber daya alam dan budaya yang berada di wilayah hidup masyarakat merupakan daya tarik pariwisata yang dapat mendatangkan wisatawan dan merupakan komoditas peningkat perekonomian. Praktik spasial masyarakat yang mulanya hanya bertindak sebagai buruh dan mitra perusahaan bertambah menjadi pemilik usaha dan dalam interaksi sosial mengusahakan terciptanya suasana nyaman dan aman bagi wisatawan. Perubahan praktik spasial ini diawali perubahan konsepsi masyarakat tentang ruang.

Tindakan adalah representasi pikiran. Praktik spasial merupakan ekspresi konsepsi masyarakat. Konsepsi mendahului praktik. Sebelum masyarakat melakukan aktivitas kepariwisataan, konsepsi tentang pariwisata lebih dulu terbentuk di alam pikiran. Masyarakat beraktivitas sesuai dengan pemikirannya. Praktik spasial yang dilakukan sejalan dengan konsepsi masyarakat terhadap ruang, yaitu biodiversitas biota laut dan keunikan budaya merupakan atraksi pariwisata yang dapat menigkatkan perekonomian. Perubahan konsepsi masyarakat menunjukkan bahwa ruang yang direncanakan bersifat politis dan determinan. Dengan kata lain, ruang representasional memiliki pengaruh terhadap ruang representasi dan secara simultan juga berdampak kepada praktik spasial.

Pola pemikiran dan tindakan masyarakat yang berubah merupakan konsekuensi dari pengaruh panjang globalisasi yang menyebabkan peralihan dari sistem pengelolaan tradisional menuju modern. Perubahan konsepsi masyarakat adalah implikasi globalisasi rekaan para penganut nilai ekonomi yang bekerja melalui strategi representasi ruang yang didalamnya terdapat beragam hasil analisis akademik atau studi ilmiah.

Pemerintah adalah aktor utama yang pemikirannya harus diubah agar sejalan dengan kepentingan ekonomi global. Melalui kebijakan pemerintah pada tahun 1980-an yang menyetujui pengembangan sektor pariwisata, ekspedisi eksplorasi sumber daya kelautan dapat dijalankan. Hasil studi menjadi rujukan pemerintah menggagas dan menetapkan kawasan konservasi dan kawasan pariwisata nasional

Keputusan pemerintah adalah bentuk kebijakan spasial. Tindakan ini merupakan proses produksi ruang secara imajinatif. Wilayah Wakatobi diimajinasikan sebagai ruang konservasi sekaligus ruang pariwisata yang pola ruangnya dapat dilihat melalui peta. Kebijakan spasial berupa representasi ruang memiliki daya pengubah pola ruang. Perubahan konsepsi masyarakat Wakatobi terhadap ruang yang dihuninya adalah implikasi dari kepentingan para penganut nilai ekonomi yang masuk melalui kebijakan spasial pemerintah.

\section{SIMPULAN}

Hasil penelitian menunjukkan bahwa ruang pariwisata Wakatobi terbentuk melalui tiga proses, yaitu: keterlibatan masyarakat dan swasta dalam pengelolaan pariwisata, kebijakan spasial penetapan Wakatobi sebagai kawasan pariwisata dan pemikiran masyarakat yang memersepsikan wilayahnya sebagai ruang pariwisata. Hubungan antara masyarakat dan swasta dimulai dari tahun 1995-an ketika Operation Wallacea dan Wakatobi Dive Resort beroperasi di Wakatobi. Kebijakan spasial yang menetapkan Wakatobi sebagai kawasan wisata alam laut pada 1995, taman nasional 1996 dan penetapan Wakatobi sebagai salah satu 10 destinasi unggulan Indonesia pada 2016 adalah upaya pemanfaatan dan perlindungan sumber daya alam laut 
Wakatobi. Perubahan persepsi masyarakat terhadap ruang hidupnya dari ruang perikanan menjadi ruang pariwisata adalah pengaruh dari hubungan ekonomi yang dilakukan dengan pihak swasta dan kebijakan spasial penetapan Wakatobi sebagai kawasan konservasi dan kawasan pariwisata.

Pariwisata adalah sektor strategis ekonomi nasional. Sektor pariwisata dikembangkan untuk meningkatkan perekonomian masyarakat dan wilayah. Pembangunan pariwisata yang baik dilakukan secara buttom-up, yang dikaji dengan memperhatikan aspirasi masyarakat. Masyarakat adalah objek sekaligus subjek pembangunan. Pengakomodiran aspirasi masyarkat dilakukan agar ruang pariwisata yang dirumuskan tidak bertentangan dengan kepentingan publik. Pembangunan berkonsep ekowisata dan berbasis masyarakat adalah strategi yang dapat digunakan dalam perencanaan pengembangan pariwisata.

\section{DAFTAR RUJUKAN}

Anggraeni, N., \& Sunaryo, B. (2015). Hubungan Perubahan Fisik Ruang dengan Kondisi Sosial Ekonomi Masyarakat di Kawasan Koridor. Jurnal Wilayah dan Lingkungan, 3(2), 79-94. https://doi.org/10.14710/jwl.3.2.79-94

Creswell, J. W. (2015). Penelitian Kualitatif dan Desain Riset (Memilih Diantara Lima Pendekatan). Yogyakarta: Pustaka Pelajar.

Fachry, M. E., Made, S., \& Halim, I. S. (2010). Dampak Objek Wisata Wakatobi Dive Resort terhadap Kondisi Sosial Ekonomi Masyarakat Pesisisir di Desa Lamanggau, Kecamatan Tomia, KabupatenWakatobi Sulawesi Tenggara. Jurnal Ponggawa, 5(1), 1-13.

Hajratul, L. O., Roslan, S., \& Sarpin. (2018). Pro Kontra Masyarakat tentang Rencana Pemberlakuan Badan Otorita Pariwisata (BOP) di Kecamatan Tomia Kabupaten Wakatobi. Jurnal Neo Societal, 3(1), 308-314.

Hanan, L. O. M. S. (2010). Kajian Strategi Pengelolaan Sumberdaya Laut oleh Masyarakat Adat dalam Kawasan Taman Nasional Wakatobi (IPB (Bogor Agricultural University)). https://repository.ipb.ac.id/handle/123456789/43858

Kosmaryandi, N., Basuni, S., Prasetyo, L. B., \& Adiwibowo, S. (2012). New Idea for National Park Zoning System: A Synthesis between Biodiversity Conservation and Customary Community's Tradition. Journal of Tropical Forest Management,

Miles and Huberman. (1994). Analisis Data Kualitatif. Terjemahan Tjetjep Rohendi Rohidi. Jakarta: Penerbit Universitas Indonesia.

Moleong, L. J. (2017). Metodologi Penelitian Kualitatif (Edisi Revisi). Bandung: PT. Remaja Rosda Karya.

Muis, A. A., Sumarmi., \& Astina, I. K. (2016). Strategi Pengembangan Ekowisata Bahari sebagai Sumber Belajar Geografi Pariwisata. Jurnal Pendidikan: Teori, Penelitian, dan Pengembangan, 1(11), 2178-2188.

Nontji, A. (2017). Ekspedisi Snellius II (1984-1985): Ekspedisi Oseanografi Terbesar dalam Kerjasama Indonesia-Belanda. Dari: http://oseanografi.lipi.go.id/datakolom/29 Ekspedisi Snellius II.pdf

Peraturan Menteri Pariwisata No. 29 Tahun 2015. (n.d.). Rencana Strategis 2015-2019 Kementerian Pariwisata. http://www.kemenpar.go.id/post/rencana-strategis-2015-2019-kementerian-pariwisata

Peraturan Pemerintah Republik Indonesia Nomor 50 Tahun 2011. (2011). Indikasi Program Pembangunan Kepariwisataan Nasional.

Pet-Soede, L., \& Erdmann, M. (2003). Rapid Ecological Assessment Wakatobi National Park. In TNC-WWF Join Program Wakatobi-Indonesia.

Prasetyo, H. (2013). Sociology of Space: Sebuah Bentangan Teoritik. Jurnal Sejarah dan Budaya, 7(2), 67-85. https:// doi.org/10.17977/sb.v7i2.4748

Purbani, D., Ramdhan, M., Arifin, T., Salim, H., \& Novianti, N. (2014). Karakteristik Pantai Taman Nasional Wakatobi dalam Mendukung Potensi Wisata Bahari: Studi Kasus Pulau Wangi-Wangi. Jurnal Depik, 3(2), 137-145. https:// doi.org/10.13170/depik.3.2.1539

Purwanto, P., Astina, I. K., \& Suharto, Y. (2015). Pemanfaatan Sistem Informasi Geografi untuk Pemodelan Spasial Pengembangan Wisata Pantai di Kabupaten Tulungagung. Jurnal Pendidikan Geografi, 20(1), 12-23. https:// /doi.org/10.17977/um017v20i12015p012

Rachman, N. F. (2018). Memahami Reorganisasi Ruang melalui Perspektif Politik Agraria. BHUMI: Jurnal Agraria dan Pertanahan, 1(1), 33-44

Ramantika, H., Murti Nugroho, A., \& Ernawati, J. (2015). Perubahan Ruang pada Tradisi Sedekah Laut di Kampung Nelayan Karangsari Kabupaten Tuban. El-Harakah, 16(2), 203. https://doi.org/10.18860/el.v16i2.2776

Saputro, T. eko \& Q. (2013). Eksplorasi Potensi Fisik Kawasan Pantai Jogan, Pantai Nglambor, dan Pantai Siung sebagai Kawasan Wisata Pantai. Jurnal Sinektika, 13(1), 1-10.

Saraswati. (2006). Kearifan Budaya Lokal Dalam Persfektif Teori Perencanaan. Jurnal PWK Unisba, 6(2).

Setiadi, H. (2007). Penataan Ruang, Integrasi Nasional, dan WilayahTertinggal: Sebuah Tinjauan Politik Keruangan Nasional. Seminar "Membangun Infrastruktur sebagai Salah Satu Solusi Mengurangi Kesenjangan Antar Daerah” Tanggal 25-26 Juli 2007 di Hotel Grand Cempaka, Jakarta. https://www.researchgate.net/publication/324794206_ Penataan_Ruang_Integrasi_Nasional_dan_WilayahTertinggal_Sebuah_Tinjauan_Politik_Keruangan_Nasional 
1503 Jurnal Pendidikan, Vol. 4, No. 11, Bln November, Thn 2019, Hal 1496-1503

Tempo.co. (2016). Ribuan Warga Wakatobi Demo Tolak Badan Otorita Pariwisata. pp. 2-4. https://nasional.tempo.co/ $\mathrm{read} / 774019 /$ ribuan-warga-wakatobi-demo-tolak-badan-otorita-pariwisata

Udu, S. (2017). Modal Budaya dan Modal Sosial Dalam Pengembangan Badan Otorita Pariwisata Wakatobi. Konferensi Internasional Bahasa, Sastra dan Budaya Daerah Indonesia, (September), 1-14.

World Tourism Organitation. (2019). International Tourist Arrivals Reach 1.4 Billion Two Years A head of Forecasts. http://www2.unwto.org/press-release/2019-01-21/international-tourist-arrivals-reach-14-billion-two-years-aheadforecasts 